\title{
The Savage Within
}

\author{
Yu-Miao Yang (Corresponding author) \\ Department of Applied English, I-Shou University ,Taiwan \\ Email: yyangp@isu.edu.tw
}

Received: 07-04-2017

Published: 01-11-2017
Accepted: 29-05-2017

doi:10.7575/aiac.ijalel.v.6n.6p.53
Advance Access Published: September 2017

URL: http://dx.doi.org/10.7575/aiac.ijalel.v.6n.6p.53

\begin{abstract}
Heart of Darkness is often viewed as an allegory that relates the tragic demise of the colonists and the annihilation of the noble ideas they hold. In Heart of Darkness, the colonial theme is best examined through the fate of Kurtz, the protagonist of the novel who emerges from the surface of conventional European values as a man of varied talents and high culture. Equipped with moral ideas, Kurtz travelled to the Congo to campaign for noble ideals, yet having arrived in a primeval place, the uncivilised wilderness awakened his "brutal instincts" and "monstrous passion". He submitted himself utterly to the temptation to "go native", descending into a moral and physical state of degeneration. He is to become a savage man, consumed by the tangled and unforgiving jungle. The life and death of Kurtz in the wilderness helps to demonstrate that the treat of barbarism comes from indeed within civilisation itself. This paper thus seeks to examine the savage humanity by scrutinising Kurtz's Mephistophelian transformation in the heart of darkness.
\end{abstract}

Keywords: Conrad, Barbarism, Colonialism

\section{Introduction}

Travelling from the presumed centre of the civilised world to a primitive territory, Marlow's peregrination in Heart of Darkness is often viewed as a spiritual voyage of self-discovery. To précis the impact this experience has upon him, Marlow states: 'It was the farthest point of navigation and the culminating point of my experience. It seemed somehow to throw a kind of light on everything about me - and into my thoughts". What Marlow brings out from the Dark Continent is realistic and detailed depiction of hair-raising horror and miseries the colonists caused in the name of civilisation and progress. Heart of Darkness is therefore often viewed as an allegory that relates the tragic demise of the colonists and the annihilation of the noble ideas they hold. The colonial theme is best examined through the fate of Kurtz, the protagonist of the novel who emerges from the surface of conventional European values as a man of varied talents and high culture. Equipped with moral ideas, Kurtz travelled to the Congo to campaign for noble ideals, yet having arrived in a primeval place, the uncivilised wilderness awakened his "brutal instincts" and "monstrous passion". He submitted himself utterly to the temptation to "go native", descending into a moral and physical state of degeneration. He is to become a savage man, consumed by the tangled and unforgiving jungle.

\section{Discussion}

Although the storyline of this novella obits around Kurtz, Conrad actually denies us a direct access to Kurtz for most of the narration, while concretely creating a fantastic image in his stead with Marlow's assistance. Through Marlow's progressive revelation, a dim picture of Kurtz gradually emerges: "It was a distinct glimpse ... the dugout, four paddling savage, and the lone white man turning his back suddenly on the headquarters, on belief, on thoughts of home perhaps, setting his face towards the depth of the wilderness, towards his empty and desolate station" (34). This picture encapsulates Kurtz's idealistic as well as romantic reflection as an individual who has turned his back on home for the wilderness, trading the stricture of civilisation for the lure of enforcing his own beliefs. With conviction that rivals a crusader's, Kurtz sees himself as the first man in this savage land, a messenger for the Enlightenment.

In truth, Kurtz's approach to Africa rests firmly on the expansion of material interests, believing strongly that Africa could only be rescued from darkness through the establishment of the ivory trade. Calling upon the power of commercial interests to boost social development, Kurtz's proposal for cultivating Africa corresponds to the one Charles Gould tenders for Costaguana in Nostromo. As an idealistic intellectual educated in the West who deeply committed himself to the Western idea of civilisation, like Kurtz, Charles Gould postulates that the world can be made a better place by good faith and unselfish idealism. In Costaguana, a poverty-stricken country almost ruined by continuous coup détat, Charles Gould sees the success of economic progress as the only useful, solid force capable of underpinning the law, restoring justice for an oppressed people, and thereby turning the country around. Sentimentalising the role material interests play, Charles Gould insists

What is wanted [in Costaguana] is law, good faith, order, security. Anyone can declaim about these things, but I pin my faith to material interests. Only let the material interests once get a firm footing, and they are bound to impose the conditions on which alone they can continue to exist. That's how your money-making is justified 
here in the face of lawlessness and disorder. It is justified because the security which it demands must be shared with an oppressed people. A better justice will come afterwards. That's your ray of hope (Nostromo, $81)$.

A better future will come, in Charles Gould's mind, yet only through the triumph of relentless economic development. Commercial interests, in this respect, become the means of progress and enlightenment. Acting as an agent of capitalist encroachment, Kurtz echoes the same sentiment in Heart of Darkness when he claims "each station should be like a beacon on the road towards better things, a centre of trade of course but also for humanising, improving, instructing" (34). Both Charles Gould and Kurtz seek to establish their credentials with respect to the benefits of capitalist development; however, the juggernaut of capitalism, under whichever façade, soon ultimately consumes all individual bravado.

Indeed, in the name of civilisation and Enlightenment, what both Charles Gould and Kurtz ignore is the utter exploitation they as colonists have inflicted. In Heart of Darkness, as an imperial trader, however idealistic, Kurtz has much in common with his sordid fellow agents. In fact, despite the quixotic image he projects and haughty rhetoric he pronounces, he is an even greater imperialist trader than his "profit-seeking" colleagues, sending in "as much ivory as all the others put together" (22). The ivory, once given Kurtz as a symbol of his hero's quest, now becomes the measure of his guilt.

Reading this oil painting as a silent statement of Kurtz's crusade into the wilderness, it effectively foretells Kurtz's moral downfall. The oil painting reveals the self-righteous confidence the colonists exude in their relentless expeditions in Africa. Unable to recognise the tensions and contradictions intrinsic to the enterprise of imperialism, Europeans delude themselves into believing the noble causes they claim to serve. As in Kurtz's case, he initially positions himself as an oracle who sees through the hypocrisy of colonialism and is determined to become the true advocate for Enlightenment values. Ironically and sadly, however, whilst he sets out to be the torch, Kurtz turns to be part and parcel of the Enlightenment myth that blindfolds Europe.

The image of Africa has for centuries been thought of as 'evil, ignorant, corrupt and atrocious", in contrast to the image of Europe as "good, true, pure and beautiful" (Parry 1983, pp. 4-5). For the western world, without ordered political and social structures and objective standard of civilisation, the mysterious, but vicious Africa is an unenlightened place waiting for salvation. Of course, with rapid imperial expansion and Western material interests increasingly focusing on Africa, salvation did not come too late. Identifying themselves with Atlas, who bore the heavens on his shoulders, European colonists pledged to bring the savage African out of the darkness of chaos and into the light of civilisation. As a result, innumerable European adventurers explored the so-called Dark Continent, promising to bring law and order to Africa. Sadly, the torch they held serves only to illuminate the evil greed and horrible nature of imperial aggrandisement. Instead of salvation, the Europeans burdened the natives with chaos, wretchedness and widespread displacement. In Heart of Darkness, Conrad sardonically portrays these rapacious colonists as "faithless pilgrims" or ruthless invaders from a "spiritless alternative world" (Brantlinger 1988, p.258). European adventurers soon succumb to their unbridled craving for power and wealth, abandoning every vestige of the moral and human ideals upon which civilisation is founded (Conrad, 1998). In An Outpost of Progress, Conrad satirically implies that the colonialists will, eventually, form themselves from the heart of jungle. Indeed, "outside all social restraints and hypocrisies, against the backdrop of native life", the world of the savage becomes a "perfect setting for men who had escaped the reality of civilisation" (Arendt 1968, p.70).

The first inkling of Kurtz's conversion comes to light in a seventeen-page report he composes to the International Society for the Suppression of Savage Customs for its further instruction. Kurtz begins with the argument that "we whites, from the point of development we had arrived at, must necessarily appear to [savages] in the nature of supernatural beings - we approach them with the might as of a deity" (Conrad 1988, p.50). Although written in the name of progress, of "good practically unbounded", at the bottom of the report's last page, "luminous and terrifying like a flash of lightning in a serene sky", Kurtz has scrawled "Exterminate all the brutes!" (Conrad 1988, p.51). This scrawled postscript, viewed as an evidence of a private assertion, apparently suggests that for Kurtz, the only way to salvaging the Dark Continent is to practice genocide. Laid behind this horrid statement is Kurtz's prescription for a modern world, a world that exists only in the shape of battlefield, where the uncivilised must be totally subjugated or, ideally, exterminated. Kurtz's report recalls a familiar argument made by the Professor in The Secret Agent, who also seeks his own brand of social justice by means of terror. In proclaiming extermination for "the only way of progress", the Professor reveals his vision of progress, which is committed not to rebuilding society upon progressive ideals, but merely to its destruction (Conrad 1994, 263). However, because of his total self-nihilism, the Professor is incapable of engaging in the social revolution he advocates. Far from being the enthusiastic revolutionary he claims to be, the Professor is actually a boastful, but immobilised armchair "activist". In contrast with the Professor's impotence in action, Kurtz's will-power drives him to exercise imperial power to its extreme: his chief weapon is his will-power - the kind of full-blown personal terrorism which comes to characterise his endeavours.

Indeed, in Heart of Darkness, as an imperial trader as well as the embodiment of European's noblest values, however idealistic, Kurtz's approach to Africa does have much in common with that of his sordid fellow agents. In fact, despite the quixotic image he projects and the haughty rhetoric he pronounces, he is an even greater imperialist trader than his "profit-seeking" colleagues, sending in "as much ivory as all the others put together" (Conrad 1988, p.22). The ivory, once given Kurtz as a symbol of his hero's quest, now becomes the measure of his guilt. 
Worshipped by the natives, the divine roles Kurtz takes on is no longer that of a Prometheus-like deity, on the contrary, approaching the natives with "thunder and lightning", Kurtz transforms from an idealist to the furious God similar to that of the Old Testament (Cox 1974, p.81). Those heads encircling Kurtz's outpost, which are glittering like ivory balls in the sunshine, are not "ornamental but symbolic", bearing the evidence of how far he "lacked restraint in the gratification of his various lusts, that there was something wanting in him - some small matter which when the pressing need arose could not be found under his magnificent eloquence" (Conrad 1988, p.57). When Marlow confronts Kurtz in the forest, he confronts a man in total isolation. There is no standard or sentiment to which Marlow can appeal, Kurtz has not just "kicked himself loose of the earth", he has indeed "kicked the very earth to pieces" (Conrad 1988, p.65).

It's always intriguing to see the fall of someone who has been set on a pedestal for the virtues he apparently represents; yet in Kurtz's case, as an advocator of imperialism, Kurtz's fall and transformation at the heart of jungle becomes symbolic. Alone in the forest, Kurtz has lost a community that helps to define his social and racial identity, so he becomes an isolated soul questing after his worthiness in the geopolitical as well as moral wasteland. In the hostile jungle, the primeval wilderness arouses Kurtz's dark impulses by whispering things to him about himself, things that echoed in his head because he was "hollow at the core":

[T]he wilderness had found him out early, and had taken on him a terrible vengeance for the fantastic invasion. I think it had whispered to him things about himself which he did not know, things of which he had no conception till he took counsel with this great solitude - and the whisper had proved irresistibly fascinating. It echoed loudly within him because he was hollow at the core (Conrad 1988, pp.57-8).

More significantly, as Marlow observed,

[T] he heavy mute spell of the wilderness that seemed to draw him to its pitiless breast by the awakening of forgotten and brutal instincts, by the memory of gratified and monstrous passion. This alone, I was convicted, had driven him out to the edge of the forest, to the bush, towards the gleam of fires, the throb of drums, the drones of weird incantations; this alone had beguiled his unlawful soul beyond the bounds of permitted aspirations ... (Conrad 1988, p.65).

It is obvious that Marlow attributes Kurtz's moral degeneration to the deprivation of a community, which would have helped to restraints him. Yet it is undeniable that, carrying the arrogant isolation of the colonialist to its extreme, Kurtz has lost not just self-restraint, but any notion of moral conduct. Therefore, Marlow's reasoning would soon sound like an excuse to Hannah Arendt, who claims that

"Many of these adventurers had gone mad in the silent wilderness of an overpopulated continent where the presence of human beings only underlined utter solitude, and where an untouched, overwhelmingly hostile nature that nobody had ever taken the trouble to change into human landscape seemed to wait in sublime patience for the passing away of the fantastic invasion of man. But their madness had remained a matter of individual experience and without consequence" (Arendt 1966, p.191).

However, can such an experience, as proclaimed by Arendt, remain relevant only to the individuals? Reading Marlow's depiction of the colonialism at work at the heart of darkness, the answer cannot be more poignant.

Dedicated himself to the philanthropic task of illuminating the Dark Continent, Kurtz has gone farther into the savage world of Africa than any other faithless agents have, at the expanse of great solitude. This mental and physical alienation that Kurtz has endured in the depth of the jungle turns his mind into an island. Yet "no man is an island", say John Donne, insisting that no individuals can exist without the rest of society. Donne considers solidarity essential to human existence, for the interdependence between individuals helps to define humanity. Solidarity is Janus-faced, however; it can work for gong-ho butchery as well as humanitarian compassion. On the one hand, it provides an identity to which an individual subscribes; one the other, by providing this security, it demands a minimum obedience to consensus, which is, at times, unquestionable. Whoever violates this golden rule of solidarity is therefore condemned to exile.

This is the "hidden truth" that Marlow discovers in the deepest of the jungle, or rather at the innermost of man's heart. And the knowledge is difficult for Marlow to share with his fellow Europeans. Because "with solid pavement under [their] feet, surrounded by kind neighbours ready to cheer [them] or fall on [them], stepping delicately between the butcher and the policeman", they cannot possibly image "what particular region of the first ages of man's untrammelled feet may take him into by the way of solitude - utter solitude without a policemen - by the way of silence - utter silence, where no warning voice of a kind neighbour can be heard whispering of public opinion" (Conrad 1988, p.50). Marlow remains silent about his epic journey to the African wilderness, thereby allowing his fellow Europeans to continue to live in a world of "sunny illusion" (Tucker 1975, p.30).

The best lesson we learn from Kurtz's physical and mental decline perhaps lies in its exposure of the savage aspects of humanity. By giving no names except Kurtz and Marlow to his characters, Conrad seems to imply that anyone, however romantic and idealistic, in a place like colonial Africa where "everything can be done", would easily become an instrument for imperial exploitation and eventually fall for the temptation of going native. They soon stray from the self-assigned mission and become the irredeemable imperialists, the lost souls who easily relieve themselves of "the burden of the white men". 


\section{Conclusion}

In Author's Note to Heart of Darkness, Conrad claims that the book is “experience pushed a little (and only very little) beyond the actual facts of the case for the perfectly legitimate purpose of bringing it home to the minds and bosom of the readers" (Conrad 1988, p.4). What Conrad brings out from the centre of Africa is a personal record of things "seen and done" in the Congo region in 1889. Therefore, the universal and prophetic value of Kurtz's story lies in its recognition of the potentialities of moral deconstruction not far beneath the surface of civilised society. Kurtz's various vanities are forms of one abstract desire in one man who has seen through all conventional satisfactions, and who has been given the chance to exercise unlimited power. Heart of Darkness is Conrad's allegory, his thoughtful warning that without the consistent framework of moral community, all civilizational values can diminish into the rhetoric of expediency. After all, the darkness lurks quietly in the corner of human heart, as we are not as far removed from barbarism as we like to think. The threat of barbarism comes not from the heart of jungle, but from within civilisation itself.

\section{References}

Arendt, H. (1966). The Origins of Totalitarianism. London: Allen \& Unwin.

Arendt, H. (1968). Imperialism. New York: Harcourt, Brace \& World.

Brantlinger, P. (1988). Rules of Darkness. Ithaca \& London: Cornell University Press.

Conrad, J. (1998). A Personal Record, ed. Mara Kalnins. London: Penguin.

Conrad, J. (1994). The Secret Agent: A Simple Tale. London: Penguin.

Conrad, J. (1988). Heart of Darkness. New York \& London: Norton \& Company.

Cox, C. (1974). Joseph Conrad: The Modern Imagination. London: J. M. Dent \& Sons Ltd..

Parry, B. (1983). Conrad and Imperialism. London: The McMillan Press LTD..

Tucker, M. (1976). Joseph Conrad. New York: Frederick Ungar Publishing Co.. 